\title{
ANALISIS MODEL KEPUASAN TERHADAP PEMBELIAN ULANG
}

\section{Naili Farida}

Fakultas Ilmu Sosial Dan Ilmu Politik, Universitas Diponegoro, Semarang, Indonesia

\section{Info Artikel}

Sejarah Artikel:

Diterima Juli 2014

Disetujui September 2014

Dipublikasikan September 2014

Keywords:

Brandequity;

Customer Value;

Lifestyle;

Satisfaction;

Repurchase.

\begin{abstract}
Abstrak
Tujuan penelitian ini yaitu untuk menguji pengaruh brand equity, nilai pelanggan dan lifestyle yang dimediasi kepuasan konsumen terhadap pembelian ulang produk gadget di Kota Semarang. Responden dalam penelitian ini adalah seluruh konsumen yang telah melakukan pembelian produk gadget merek Samsung, sebanyak 120 orang. Teknik sampling yang digunakan yaitu purposive sampling. Teknik analisis yang digunakan yaitu Partial Least Square (PLS). Hasil penelitian menunjukkan bahwa terdapat pengaruh brand equity terhadap kepuasan, namun dalam konteks lifestyle dan nilai pelanggan tidak ada pengaruh terhadap kepuasan. Sedangkan kepuasan menunjukkan adanya pengaruh terhadap pembelian ulang. Diharapkan dari hasil penelitian ini mampu meningkatkan pembelian ulang melalui brand equity, lifestyle dan nilai pelanggan dalam konteks kepuasan.
\end{abstract}

\section{THE ANALYSIS OF SATISFACTION MODEL ON RE-PURCHASE}

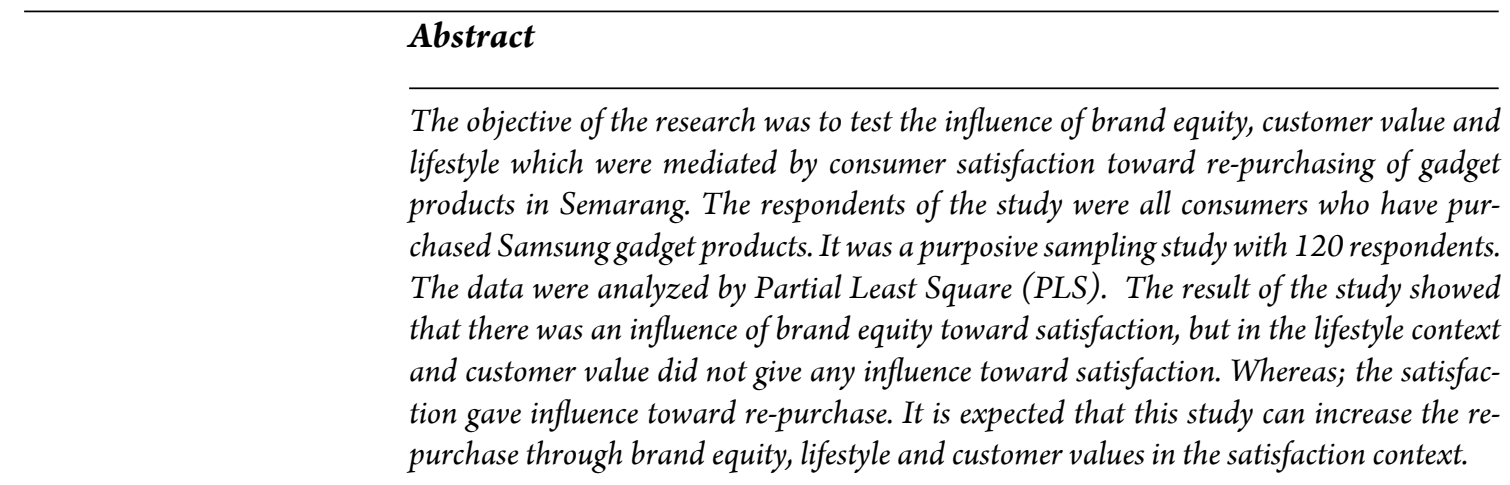

JEL Classification: M3, M31

\footnotetext{
Alamat Korespondensi:

Jalan Prof. Soedharto, SH Tembalang, Semarang, Jawa Tengah 50275

E-mail: faridanaili@ymail.com
} 


\section{PENDAHULUAN}

Brand dapat berupa nama, simbol, atau lambang yang mengingatkan konsumen akan suatu produk atau jasa. Produk atau jasa yang mempunyai brand mampu memberikan nilai tambah sehingga harga bisa lebih tinggi yakni dengan produk yang sama namun harga berbeda. Menurut Aaker (1997), ekuitas merek adalah terbentuk dari lima komponen yaitu: brand awareness, brand loyalty, perceived quality, brand association and other propietary brand assets. Dalam penelitian ini digunakan 4 komponen yaitu kesadaran merek, kualitas layanan diterima, asosiasi merek, dan loyalitas merek. Penelitian Aaker (1997) menjelaskan bahwa, ada 4 dimensi dalam brand equity yaitu: (1) brand awarness; (2) perceived quality product; (3) brand association, serta (4) brand loyalty yaitu loyalitas terhadap merek produk. Penelitian Kotler (2002), menemukan bahwa para pelanggan menginginkan nilai maksimum, dengan dibatasi oleh biaya pencarian serta keterbatasan pengetahuan, mobilitas dan penghasilan. Mereka membentuk suatu harapan akan nilai dan bertindak berdasarkan hal itu. Selanjutnya, Kottler (2002), menyebutkan bahwa nilai bagi pelanggan (customer delivered value) adalah selisih antara nilai pelanggan total dan biaya pelanggan total. Nilai pelanggan total (total customer value) adalah sekumpulan manfaat yang diharapkan oleh pelanggan dari produk atau jasa tertentu.

Penelitian Holbrook dan Hirschman (1982) menemukan bahwa, nilai adalah preferensi yang bersifat relatif (komparatif, personal dan situasional) yang memberi ciri pada pengalaman sesorang dalam berinteraksi dengan beberapa obyek. Nilaimelibatkan sebuah preferen dengan suatu kecondongan yang menguntungkan kesukaan, pengaruh positif, atau menilai sesuatu sebagai hal yang baik. Hal ini juga melibatkan interaksi antara subyek dan obyek. Nilai berkaitan dengan pengalaman yang bukan hanya menyangkut pembelian obyek, tetapi juga konsumen dan penggunaan suatu jasa. Penelitian Sheth et al. (1991) menemukan bahwa, definisi nilai adalah lima kebebasan konsumsi nilai dari perilaku konsumen. Pilihan konsumen adalah hasil dari nilai tersebut. Secara empiris, konsep nilai dilapangan ada 200 studi yang membedakan situasi konsumsi ada lima dimensi yaitu: (1) nilai fungsional; (2) nilai sosial; (3) nilai emosional; (4) nilai epstemik; serta (5) nilai kondisional. Pengambilan keputusan konsumen bisa dipengaruhi oleh satu atau semua lima nilai konsumsi. Disiplin variasi termasuk ekonomi, sosiologi, beberapa cabang dari psikologi pemasaran dan perilaku konsumen.

Perilaku konsumen muncul akibat dorongan faktor belum terpenuhinya kebutuhan dan keinginan serta desire sesesorang yang menimbulkan tension dan tension menjadi faktor pemicu individu untuk berperilaku dalam mencapai tujuan yang diinginkan. Apabila tujuan dapat dipenuhi, maka tension akan berkurang (Wijaya, 2009). Penelitian Schiffman dan Kanuk (2004) menemukan bahwa, semua perilaku konsumen berorientasi pada tujuan namun, pengaruh pembelajaran dan proses kognitif akan menjadi faktor yang mempengaruhi perilaku konsumen. Menurut Smith dan Lutz (1996), ada 4 (empat) kategori yang menjadi motif dalam proses pembelian konsumen karena lifstyle yaitu: (1) utilitarian purchases (pembelian produk yang bermanfaat); (2) indulgence (kesukaan atau memanjakan diri); (3) lifestyle luxuries (gaya hidup mewah); serta (4) aspirational luxuries (hasrat kemewahan).

Kepuasan pelanggan dalam pemasaran hubungan dapat menjadi faktor penentu kunci hubungan antara penyedia jasa dan pelanggan (Henning Thurau \& Klee, 1997; Fatona, 2010). Konsep indikator kepuasan konsumen (Ferdinand, 2013) ada 4 yaitu: (1) kepuasan atas kinerja produk inti; (2) puas atas kinerja atribut produk periferal; (3) puas atas manfaat produk; serta (4) puas akan mutu produk. Pembelian ulang adalah sikap perilaku konsumen dimana melakukan pembelian sebuah produk lebih dari satu kali (Swasta, 2002). Setelah melakukan pembelian produk atau jasa, konsumen 
akan melakukan evaluasi pasca pembelian yang terdiri dari dua hal yaitu kepuasan dan ketidakpuasan terhadap produk atau jasa. Ketidakpuasan produk atau jasa oleh konsumen, akan menyebabkan konsumen berpindah atau tidak melakukan pembelian kembali terhadap brand atau merek yang sama tetapi konsumen akan berpindah merek. Sebaliknya, konsumen yang memperoleh kepuasan terhadap merek atau brand yang dibeli, maka akan melakukan pembelian kembali dilain waktu.

Brand equity atau ekuitas merek diperoleh dari posisi pasar strategik dari merek produk atau jasa dengan memperoleh kepercayaan dari konsumen terhadap merek tesebut (Tjiptono, 2011). Selanjutnya, kepercayaan konsumen dapat menciptakan relasi atau hubungan antara merek dengan pelanggan sehingga dapat mengurangi resiko dalam pembelian dan mendorong preferensi merek. Lebih lanjut pelanggan yang telah melakukan pembelian berdasarkan ekuitas merek akan memperoleh kepuasan, sedangkan kepuasan dalam pemasaran hubungan dapat menjadi faktor penentu hubungan antara penyedia jasa dengan pelanggan (Henning Thurau \& Klee, 1997).

$\mathrm{H} 1$ : Brand equity berpengaruh terhadap kepuasan

Nilai pelanggan adalah hasil yang diperoleh konsumen berkaitan dengan manfaat produk yang diterima konsumen lebih dari produk dan jasa yang ditawarkan pada daur hidup pelanggan. Selajutnya Sheth et al. (1991), menyatakan ada 5 dimensi dari nilai pelanggan yaitu: (1) nilai fungsional; (2) nilai sosial; (3) nilai emosional; (4) nilai epistemik; serta (5) nilai kondisional. Konsumen dalam melakukan pembelian produk atau jasa salah satu yang diharapkan adalah adanya nilai atau value dari produk atau jasa tersebut. Selanjutnya, jika produk atau jasa tersebut mampu memberikan nilai tambah, maka konsumen akan merasakan kepuasan dan sebaliknya. Jika tidak dapat memberikan nilai-nilai tambah kepada konsumen, maka konsumen akan merasakan ketidakpuasan.
$\mathrm{H} 2$ : Nilai pelanggan berpengaruh terhadap kepuasan

Lifestyle atau gaya hidup adalah variabel yang dapat digunakan sebagai salah satu cara dalam membagi segmentasi pasar. Pembagian pasar dapat dirinci berdasarkan cara menghabiskan waktu beraktifitas, kepercayaan, karakteristik sosial ekonomi seperti pendapatan, pendidikan, serta lifestyle yang berfokus pada dimensi (Lamb et al., 2001). Lebih lanjut Smith dan Lutz (1996), membagi 4 (empat) kategori konsumen berdasarkan lifestyle yaitu: (1) utilitarian purchase (pembelian karena manfaat produk); (2) indulgence (kesukaan) produk; (3) life luxuries (gaya hidup mewah); serta (4) aspirational luxuries (hasrat kemewahan). Gaya hidup atau lifestyle adalah bagian dari perilaku konsumen. Konsumen melakukan pembelian terhadap produk karena produk tersebut mampu memberikan kepuasan.

H3: Lifestyle berpengaruh terhadap kepuasan

Kepuasan adalah salah satu faktor penting yang diharapkan oleh konsumen dalam melakukan pembelian suatu produk atau jasa. Faktor kepuasan akan diperoleh konsumen dalam proses konsumsi atau consumption experience. Setiap konsumen dapat memberikan pernyataan persepsi terhadap kepuasan yang diperoleh dan secara kolektif akan memberikan penilaian total (Quitty et al., 2000). Berdasarkan hal tersebut, kepuasan konsumen diprediski secara signifikan atau bermakna dapat menimbulkan perilaku pembelian ulang untuk masa yang akan datang.

$\mathrm{H} 4$ : Kepuasan berpengaruh terhadap pembelian ulang

Berdasarkan Gambar 1 dijelaskan bahwa, kerangka berpikir yang dijelaskan adalah Pembentukan pembelian ulang dipengaruhi oleh faktor kepuasan konsumen, brand equity, nilai pelanggan, dan lifestyle serta kepuasan berperan juga sebagai variabel moderating antara variabel pembelian ulang dengan brand equity, nilai pelanggan dan lifestyle. 
Naili Farida / Analisis Model Kepuasan terhadap Pembelian Ulang

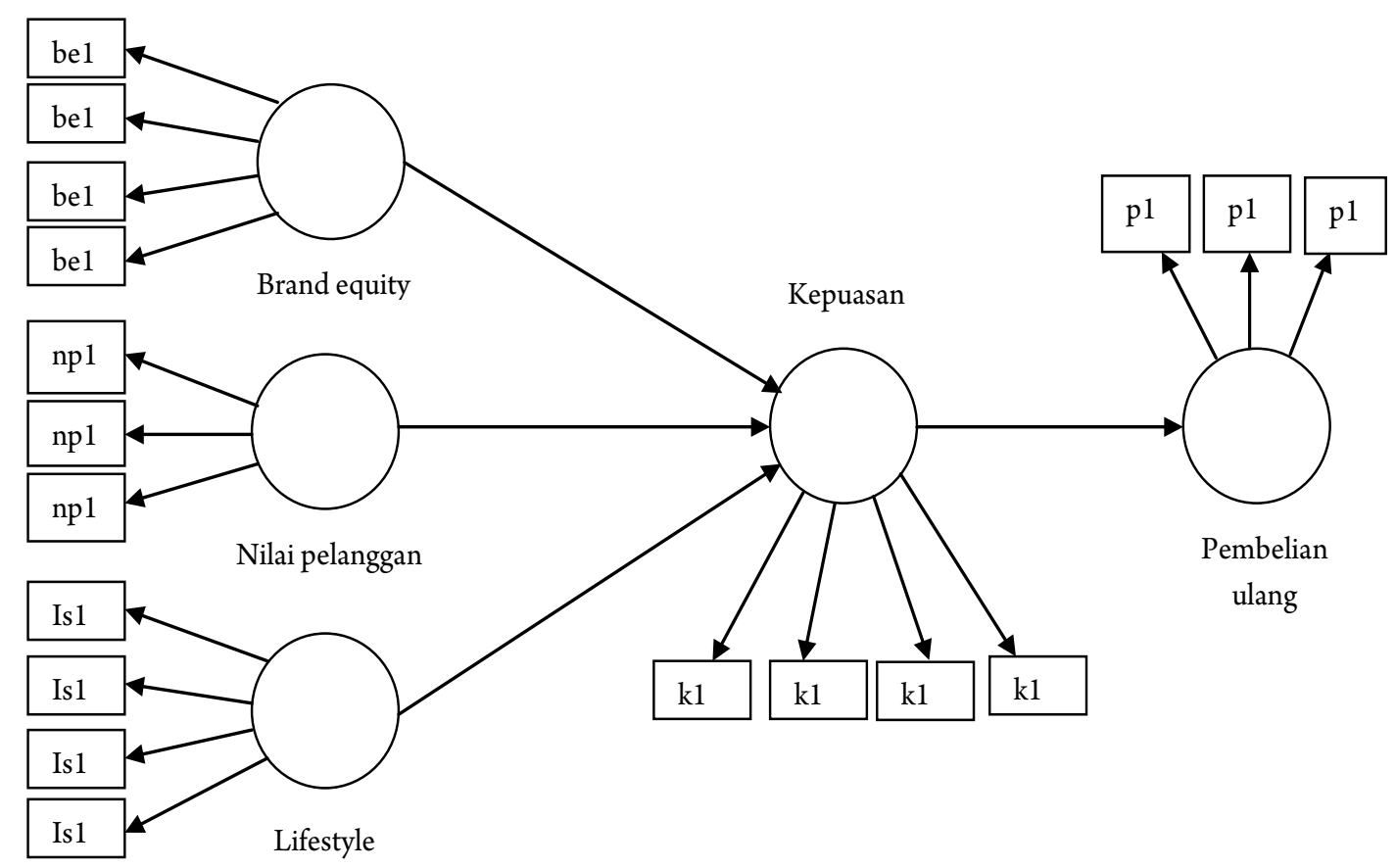

Gambar 1. Kerangka Pemikiran Teoritis

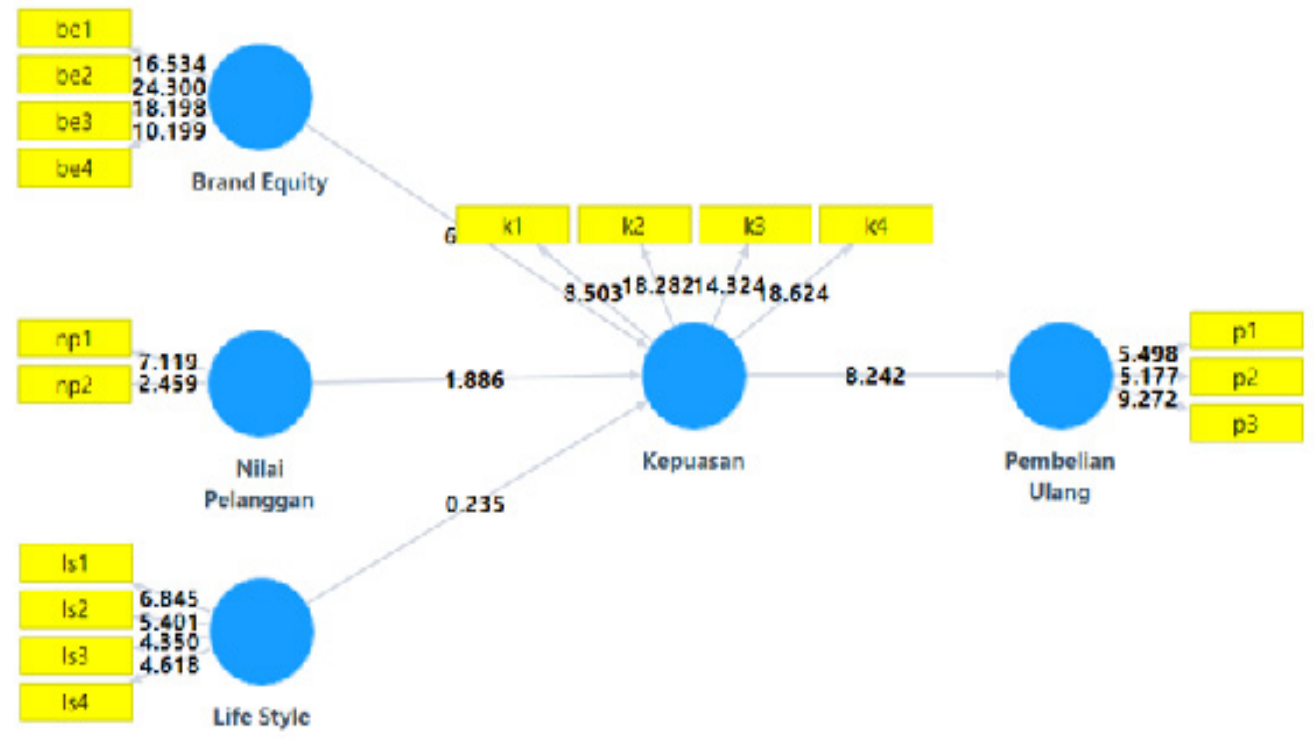

Gambar 2. Diagram Jalur Hasil Output PLS Setelah Model Fit 


\section{METODE}

Penelitian ini menggunakan pendekatan kuantitatif melalui metoda survei, yaitu dengan menyebarkan kuesioner kepada para responden. Responden akan diminta untuk menjawab pertanyaan. Populasi dalam studi ini adalah seluruh konsumen pengguna gadget samsung. Studi ini menggunakan teknik sampel purposive sampling. Kriteria responden yaitu: responden memiliki gadget merek samsung, berusia 17 tahun, serta bersedia diwawancarai. Obyek penelitian dealer resmi produk gadget Samsung di Kota Semarang. Penarikan sampel dilakukan secara accidental sampling, sebanyak 120 orang. Pengukuran yang digunakan yaitu dengan skala Likert yaitu: (1) sangat setuju (SS); (2) setuju (S); (3) nentral (N); (4) tidak setuju (TS); serta (5) sangat tidak setuju (STS). Teknik analisis yang digunakan dalam penelitian ini adalah Partial Least Square (PLS).

\section{HASIL DAN PEMBAHASAN}

Setelah dilakukan analisis sebelumnya, ada satu indikator yang tidak signifikan. Indikator yang tidak signifikan tersebut, yakni indikator np3 yang kemudian dihapuskan, sehingga diperoleh hasil seperti pada Gambar 2, yang menunjukkan bahwa model telah fit. Tampak bahwa nilai loading factor semua indikator sudah lebih dari 0,5 , dengan demikian dapat disimpulkan bahwa semua indikator di dalam model sudah fit. Outer Model atau Measurement Model adalah penilaian terhadap reliabilitas dan validitas variabel penelitian. Ada tiga cara untuk menilai outer model yaitu dengan convergent validity, discriminant validity, dan composite reliability. Hasil dari outer model menunjukan hasil pengujian reliabilitas dan validitas untuk masing-masing variabel.

\section{Convergent Validity}

Convergentvalidity darimodel pengukuran dengan refleksif indikator dinilai berdasarkan korelasi antara item score/component score yang diestimasi dengan software Smart PLS. Menurut Ghozali (2006), untuk penelitian tahap awal dari pengembangan skala pengukuran nilai loading 0,5 sampai 0,6 dianggap cukup memadai.

\section{Average Varianve Extracted}

Uji lainnya adalah menilai validasi dengan melihat nilai Average Variance Extracted (AVE), dipersyaratkan model yang baik adalah model yang memiliki AVE masing-masing konstruk nilainya lebih besar dari 0,50 (Ghozali, 2008). Mengenai nilai akar kuadrat AVE disajikan pada Tabel 1.

Tabel 1. Nilai Akar Kuadrat AVE (Average Varianve Extracted)

\begin{tabular}{ccc}
\hline & AVE & \\
\hline $\mathbf{B E}$ & 0,608 & 0,779 \\
$\mathbf{K}$ & 0,637 & 0,798 \\
$\mathbf{L S}$ & 0,543 & 0,736 \\
$\mathbf{N P}$ & 0,656 & 0,809 \\
$\mathbf{P U}$ & 0,502 & 0,708 \\
\hline
\end{tabular}

Sumber: data yang diolah (2014)

Pada Tabel 1 diperoleh seluruh nilai akar AVE > 0,5, hal ini menunjukkan bahwa semua variabel dalam model yang diestimasi memenuhi kriteria discriminant validity.

\section{Composite Reliability}

Nilai composite reliability dilakukan untuk menguji reliabilitas variabel. Variabel yang mempunyai reliabilitas yang baik dapat ditunjukan dengan nilai composite reliability 
maupun cronbach alpha $>0,70$. Nilai composite reliability disajikan pada Tabel 2 .

Tabel 2. Composite Reliability

\begin{tabular}{cc}
\hline & Composite Reliability \\
\hline BE & 0,860 \\
K & 0,875 \\
LS & 0,825 \\
NP & 0,789 \\
PU & 0,751 \\
\hline \multicolumn{2}{l}{ Sumber: data yang diolah $(2014)$}
\end{tabular}

Tabel 2 dapat diketahui bahwa seluruh nilai composite reliability dari masing-masing indikator sudah melebihi 0,70. Artinya dapat disimpulkan bahwa variabel penelitian sudah memenuhi syarat reliabilitas yang baik. Syarat reliabilitas lain yang harus dipenuhi adalah nilai cronbachs alpha yang ditunjukkan Tabel 3.

Tabel 3. Cronbachs Alpha

\begin{tabular}{cc}
\hline & Cronbachs Alpha \\
\hline BE & 0,783 \\
K & 0,809 \\
LS & 0,729 \\
NP & 0,505 \\
PU & 0,511 \\
\hline
\end{tabular}

Sumber: data yang diolah (2014)

Tabel 3 dapat diketahui bahwa nilai cronbachs alpha dari seluruh variabel sudah melebihi 0,50. Melihat nilai composite reliability maupun cronbachs alpha yang melebihi 0,50, maka dapat disimpulkan bahwa semua variabel mempunyai reliabilitas yang baik.

\section{Pengujian Model Struktural (Inner Model)}

Pengujian terhadap model struktural dilakukan dengan melihat nilai $R$-square yang merupakan uji goodness-fit model. Pengujian inner model atau model struktural dilakukan untuk melihat hubungan antara variabel, nilai signifikansi dan $R$-square dari model penelitian. Dalam menilai model dengan PLS dimulai dengan melihat $R$-Square untuk setiap variabel laten dependen. mengenai nilai $R$-square dari masing-masing variabel penelitian yang dipengaruhi oleh variabel lain disajikan dalam Tabel 4.

Tabel 4. $R$ Square

\begin{tabular}{cc}
\hline & RSquare \\
\hline K & 0,403 \\
PU & 0,310 \\
\hline Sumber: data yang diolah $(2014)$
\end{tabular}

Sumber: data yang diolah (2014)

Berdasarkan Tabel 4 dapat diinterpretasikan yaitu: (1) variabilitas konstruk kepuasan yang dapat dijelaskan oleh variabilitas konstruk brand equity, nilai pelanggan dan lifestyle bernilai sebesar 40,30\% sedangkan $59,70 \%$ dijelaskan oleh variabel lain diluar yang model; serta (2) variabilitas konstruk pembelian ulang dijelaskan oleh variabilitas konstruk brand equity, nilai pelanggan, lifestyle dan kepuasan yang bernilai sebesar $31,0 \%$ sedangkan $69,0 \%$ dijelaskan oleh variabel lain diluar yang model.

Tabel 5 path coefficients di atas dapat diketahui bahwa nilai original sample tertinggi terdapat pada hubungan antara brand equity terhadap kepuasan, yaitu 0,563, sedangkan nilai original sample terendah terdapat pada hubungan antara lifestyle terhadap kepuasan, yaitu sebesar 0,023. Nilai sample mean paling besar terdapat pada hubungan antara kepuasan terhadap pembelian ulang, yakni sebesar 0,571, sedangkan nilai sample mean terendah terdapat pada hubungan antara lifestyle terhadap kepuasan, yakni sebesar 0,040.

Nilai standard error (STERR) paling besar terdapat pada hubungan antara lifestyle terhadap kepuasan, yaitu sebesar 0,099, sedangkan nilai terendah terdapat pada hubungan antara kepuasan terhadap pembelian ulang, yaitu sebesar 0,068 . Nilai $t$-statistic terbesar terdapat pada hubungan antara kepuasan terdapat pembelian ulang, yaitu sebesar 8,242 , sedangkan 
Tabel 5. Path Coefficients (Mean, STDEV, T-Values)

\begin{tabular}{cccccc}
\hline & $\begin{array}{c}\text { Original } \\
\text { Sample }(\mathbf{O})\end{array}$ & $\begin{array}{c}\text { Sample } \\
\text { Mean }(\mathbf{M})\end{array}$ & $\begin{array}{c}\text { Standard Error } \\
(\text { STERR })\end{array}$ & $\begin{array}{c}\text { T Statistics }(\mid \mathbf{O} / \\
\text { STERR } \mid)\end{array}$ & P Values \\
\hline BE $->$ K & 0,563 & 0,554 & 0,089 & 6,343 & 0,000 \\
K $>$ PU & 0,557 & 0,571 & 0,068 & 8,242 & 0,000 \\
LS $->\mathbf{K}$ & 0,023 & 0,040 & 0,099 & 0,235 & 0,815 \\
NP $->\mathbf{K}$ & 0,161 & 0,176 & 0,085 & 1,886 & 0,062 \\
\hline
\end{tabular}

Sumber: data yang diolah (2014)

Tabel 6. Hasil Pengujian Hipotesis

\begin{tabular}{cccccc}
\hline Hipotesis & Koefisien & Taraf Signifikansi & t-tabel & t-statistic & Hasil \\
\hline H1 & 0,563 & $5 \%$ & 1,980 & 6,343 & H1 didukung \\
H2 & 0,023 & $5 \%$ & 1,980 & 0,235 & H2 tidak didukung \\
H3 & 0,161 & $5 \%$ & 1,980 & 1,886 & H3 tidak didukung \\
H4 & 0,557 & $5 \%$ & 1,980 & 8,242 & H4 didukung \\
\hline
\end{tabular}

Sumber: data yang diolah (2014)

nilai $t$-statistic terendah terdapat pada hubungan antara lifestyle terhadap kepuasan, yaitu sebesar 0,235 . Mengenai hasil pengujian hipotesis pada penelitian ini disajikan pada Tabel 6.

Tabel 6 hasil pengujian hipotesis bootstrapping dari analisis PLS diatas dapat diketahui bahwa hipotesis 1 dan hipotesis 4 didukung, sedangkan hipotesis 2 dan hipotesis 3 tidak didukung. H1 terdapat pengaruh antara brand equity terhadap kepuasan, artinya brand equity berpengaruh positif terhadap kepuasan. Hal ini menunjukkan bahwa dengan brand equity yang kuat, maka akan mempengaruhi kepuasan pengguna produk gadget merek samsung. Berdasarkan hasil deskripsi jawaban responden, brand equity dengan empat indikator persepsi responden yaitu: (1) mengenali dan mengingat merek (BE1); (2) keunggulan atas superioritas (BE2); (3) memori merek (BE3); serta (4) loyalitas merek (BE4) dengan skor tertingggi adalah mengenali dan mengingat kepuasan. Hal merek dan skor terendah adalah memori merek. Hal ini mencerminkan bahwa responden sangat kuat mengenali dan mengingat merek samsung kuat yang didukung dengan produk yang berkualitas.

Temuan penelitian ini mendukung beberapa riset dan teori dari Henning-Thurau dan Klee (1997) serta Tjiptono (2011), sehingga dapat disimpulkan bahwa brand equity yang tinggi akan mampu meningkatkan kepuasan konsumen. Namun penelitian ini tidak mendukung hasil penelitian Smith dan Lutz (1996). Selanjutnya, berdasarkan data diatas dapat disimpulkan bahwa $\mathrm{H} 2$ tidak didukung, artinya nilai pelanggan yang tinggi tidak berpengaruh terhadap kepuasan. Hal ini menunjukkan meskipun nilai pelanggan yang diberikan produk tinggi, namun tidak selalu mampu meningkatkan kepuasan konsumen. Hal ini tidak mendukung temuan beberapa hasil penelitian dan teori dari Quitti et al. (2000) serta Sheth et al. (1991). Berdasarkan uraian di atas dapat disimpulkan bahwa nilai pelanggan yang tinggi tidak secara langsung dapat memberikan kepuasan yang tinggi oleh konsumen. Deskripsi jawaban responden dari nilai pelanggan dengan tiga indikator yaitu: (1) persepsi responden 
melakukan pembelian produk memiliki nilai manfaat (NP1); (2) pembelian produk memiliki nilai sosial (NP2); serta 3) pembelian produk memiliki kegunaan nilai emosional (NP3). Skor tertinggi yaitu pembelian yang memiliki nilai manfaat dan skor terendah yaitu pembelian berdasarkan nilai emosional. Hal ini menggambarkan bahwa responden melakukan pembelian produk yang memiliki nilai manfaat dibanding dengan indikator yang lain.

Kemudian pada hipotesis 3 yaitu $\mathrm{H} 3$ tidak didukung dalam penelitian, artinya tidak terdapat pengaruh antara lifestyle terhadap kepuasan atau gaya hidup yang tinggi tidak selalu diikuti dengan kepuasan. Walaupun responden tidak memperoleh kepuasan produk, mereka akan tetap menggunakan, mengingat produk gadget adalah simbol dari gaya hidup. Hasil deskripsi jawaban responden menggambarkan variabel lifestyle memiliki 4 indikator yaitu: (1) pembelian produk luxury yang bermanfaat (LS1); (2) pembelian produk sesuai dengan kesukaan (LS2); (3) pembelian produk mewujudkan gaya hidup mewah (LS3); serta (4) pembelian produk karena hasrat kemewahan (LS4). Skor tertinggi adalah produk sesuai dengan kesukaan dan skor terendah pembelian produk dengan hasrat kemewahan. Ini berarti indikator lifestyle untuk pembelian produk sesuai dengan kesukaan adalah dominan dibanding dengan indikator yang lain. Temuan hasil penelitian ini menunjukkan bahwa jika produk yang digunakan berkaitan dengan gaya hidup akan dibeli, meskipun produk tersebut tidak memberikan kepuasan.

$\mathrm{H} 4$ terdapat pengaruh antara kepuasan terhadap pembelian ulang, artinya kepuasan yang tinggi berpengaruh pada pembelian ulang. Dapat disimpulkan bahwa, kepuasan berpengaruh positif dan signifikan terhadap pembelian ulang. Hal ini menunjukkan jika kepuasan konsumen meningkat, maka pembelian ulang akan meningkat pula. Temuan hasil penelitian dari Quitii et al. (2000), disimpulkan bahwa kepuasan yang tinggi akan berpengaruh untuk melakukan pembelian ulang didukung. Selajutnya jawaban responden untuk variabel kepuasan ada 4 indikator yaitu: (1) konsumen puas atas kinerja produk inti (KP1); (2) puas atas produk tambahan (KP2); (3) puas atas manfaat produk (KP3); serta (4) puas atas mutu produk (KP4). Skor tertinggi adalah konsumen puas atas mutu produk dan skor terendah adalah puas atas produk tambahan.

Selanjutnya untuk variabel pembelian ulang memiliki 3 indikator yaitu: (1) responden melakukan pembelian kembali produk merek samsung (PU1); (2) responden mampu membayar lebih mahal (PU2) ; serta (3) responden tidak akan berpindah ke merek lain (PU3). Hasil skor tertinggi menunjukkan responden melakukan pembelian ulang terhadap produk merek samsung dan skor terendah adalah responden tidak akan berpindah ke merek yang lain.

\section{SIMPULAN DAN SARAN}

Pengujian hipotesis menghasilkan temuan bahwa hasil pengujian hipotesis pertama menunjukkan bahwa brand equity berpengaruh positif dan signifikan terhadap kepuasan, artinya semakin tinggi brand equity responden terhadap produk, semakin tinggi kepuasan yang diperoleh. Hal ini juga didukung deskripsi dari jawaban responden dari empat indikator, terdapat satu indikator yang dominan yaitu responden mengenali dan mengingat brand sangat kuat. Hipotesis kedua yaitu pengujian terhadap nilai pelanggan terhadap kepuasan tidak didukung, artinya tidak terdapat pengaruh antara nilai pelanggan terhadap kepuasan. Deskripsi dari jawaban responden menjelaskan bahwa dari tiga indikator nilai pelanggan terdapat satu indikator yang dominan yaitu responden dalam melakukan pembelian produk dengan mempertimbangkan nilai manfaat yang utama.

Hipotesis ketiga yaitu hubungan lifestyle terhadap kepuasan tidak didukung, artinya tidak ada pengaruh antara lifestyle terhadap kepuasan. Jawaban responden menunjukkan ada empat indikator yang memiliki persepsi, namun yang dominan yaitu responden melakukan pembelian 
produk berdasarkan kesukaan, meskipun tidak ada kepuasan produk, tetapi dibeli mengingat produk tersebut sebagai simbol dari gaya hidup atau lifestyle. Hipotesis keempat yaitu kepuasan terhadap pembelian ulang didukung, artinya semakin tinggi kepuasan, maka semakin tinggi frekuensi pembelian ulang yang dilakukan oleh konsumen. Hasil deskripsi jawaban responden menyatakan bahwa dari tiga indikator yang dominan yaitu responden akan melakukan pembelian ulang dengan merek samsung.

Rekomendasi untuk perusahaan atau produsen brand equity dari produkgadget merek samsung perlu ditingkatkan lagi, sedangkan untuk meningkatkan asset dari produk tersebut yaitu dapat dilakukan dengan cara meningkatkan atribut dari produk inti dan atribut produk tambahan. Hasil penelitian menunjukkan bahwa responden telah mampu membedakan produk melalui atribut dengan atribut produk dari kompetitor. Agenda untuk penelitian yang akan datang sebaiknya menentukan fokus pada satu jenis produk mengingat gadget meliputi: handphone, komputer tablet, iphone, dan jumlah responden perlu ditambahkan sehingga lebih terwakili.

\section{DAFTAR PUSTAKA}

Aaker, D. 1997. Manajemen Ekuitas Merek, Edisi Kedua. Jakarta: Penerbit Spectrum.

Wijaya, B.T. 2009. Lifestyle Marketing. Servlist: Paradigma Baru Pemasaran Bisnis Jasa dan Lifestyle. Jakarta: Pustaka Utama.

Fatona, S. 2010. Kualitas Jasa yang Mempengaruhi Loyalitas dan Relevansinya terhadap Kepuasan. Jurnal Dinamika Manajemen. 1 (1): 41-46.

Ferdinand, A. 2013. Metode Penelitian Manajemen. Semarang: UNDIP Press.
Ghozali, I. 2006. Stuctural Equation Modelling, Metode Alternatif dengan Partial Least Square. Semarang: Badan Penerbit UNDIP.

Ghozali, I. 2008. Stuctural Equation Modelling, Metode Alternatif dengan Partial Least Square, Edisi Ketiga. Semarang: Badan Penerbit UNDIP.

Henning-Thurau, T \& Klee, A. 1997. The Impact of Customer Satisfaction and Relationship Quality on Customer Retention: A Critical Reassessment and Model Development. Journal Psychology and Marketing. 14 (8): 737-764.

Holbrook, M. H \& Hirschman, E. C. 1982. The Experiental Aspect of Consumption: Consumer Fantasies. Feeling and Fun. Journal of Consumer Research. 9 (2): 132-140.

Kotler, P. 2002. Manajemen Pemasaran. Alih bahasa oleh Hendra Teguh. Edisi Milenium. Jilid I Jakarta: Prenhalindo.

Lamb, C. W., Hair, J. F \& Mc Daniel, C. 2001. Marketing. Singapore: Thomson Learning.

Quitty, Mc., Shaun, F. A \& Wiley, J. B. 2000. Systematiccally, Varying Customer Satisfaction and Its Implications for Product Choise. Academic Marketing Science Review. 10.

Schiffman, L. G. L \& Kanuk, L. 2004. Perilaku Konsumen, Edisi Ketujuh. Jakarta: PT. Indeks Gramedia.

Sheth, J. N., Newman, B. I \& Gross, B. L. 1991. Why We Buy What We Buy: A Theory Consumption Values. Journal of Business Research. 49 (2): 127-138.

Smith, R. A \& Lutz, R. L. 1996. Experientalism: Conceptualization and Measurement. Journal of Advances in Consumer Research. 23.

Swasta, B. 2002. Manajemen Pemasaran Modern. Yogyakarta: Fakultas Ekonomi UGM.

Tjiptono, F. 2011. Manajemen dan Strategi Merek. Yogyakarta: ANDI Ofset. 